\title{
The Critical Early Proinflammatory Events Associated with Idiopathic Pneumonia Syndrome in Irradiated Murine Allogeneic Recipients Are Due to Donor T Cell Infusion and Potentiated by Cyclophosphamide
}

\author{
Angela Panoskaltsis-Mortari, ${ }^{\star}$ Patricia A. Taylor, ${ }^{\star}$ Thomas M. Yaeger, ${ }^{\star}$ O. Douglas Wangensteen, ${ }^{\ddagger}$ Peter B. Bitterman, $\$$ \\ David H. Ingbar, ${ }^{\S}$ Daniel A. Vallera, $\|$ and Bruce R. Blazar* \\ $*$ Department of Pediatrics, BMT Division; ${ }^{\ddagger}$ Department of Physiology; ${ }^{\S}$ Department of Pulmonary Medicine; and $\|^{\|}$Department of \\ Therapeutic Radiology, University of Minnesota, Minneapolis, Minnesota 55455
}

\begin{abstract}
We have hypothesized that lung damage occurring in the peri-bone marrow transplant (BMT) period is critical for the subsequent generation of idiopathic pneumonia syndrome (IPS), a major complication following human BMT. The proinflammatory events induced by a common preBMT conditioning regimen, cyclophosphamide (Cytoxan ${ }^{\circledR}$ ) (Cy) and total body irradiation, were analyzed in a murine BMT model. Electron microscopy indicated that Cy exacerbated irradiation-induced epithelial cell injury as early as day 3 after BMT. Allogenicity was an important contributing factor to lung injury as measured by lung wet and dry weights and decreased specific lung compliance. The most significant pulmonary dysfunction was seen in mice receiving both allogeneic $\mathrm{T}$ cells and $\mathrm{Cy}$ conditioning. IPS was associated with an influx of $T$ cells, macrophages, and neutrophils early post-BMT. Hydroxyproline levels were not increased, indicating that the injury was not fibrotic early post-BMT. As early as $2 \mathrm{~h}$ after chemoradiation, host macrophages increased in number in the lung parenchyma. Continued increases in macrophages occurred if splenic $T$ cells were administered with the donor graft. The expression of costimulatory B7 molecules correlated with macrophage numbers. Frequencies of cells expressing mRNA for the inflammatory proteins TNF- $\alpha$, IL-1 $\beta$, and TGF $\beta$ were increased. Cy accelerated the upregulation of TGF $\beta$ and increase in host macrophages. The exacerbation of macrophage activation and severity of IPS was dependent on allogeneic $T$ cells, implicating immune-mediated mechanisms as critical to the outcome of IPS. This demonstration of early injury after BMT indicates the need for very early therapeutic intervention before lung damage becomes profound and irreversible. (J. Clin. Invest. 1997. 100:10151027.) Key words: bone marrow transplant • lung injury • cytokines $\bullet$ macrophages $\bullet$ costimulatory molecules
\end{abstract}

Address correspondence to Angela Panoskaltsis-Mortari, Ph.D., University of Minnesota, Department of Pediatrics, Division of Bone Marrow Transplantation, Box 484 UMHC, 420 Delaware Street S.E., Minneapolis, MN 55455. Phone: 612-626-2950; FAX: 612-624-3913; E-mail: panos001@maroon.tc.umn.edu

Received for publication 22 January 1997 and accepted in revised form 3 June 1997.

J. Clin. Invest.

(c) The American Society for Clinical Investigation, Inc. 0021-9738/97/09/1015/13 \$2.00

Volume 100, Number 5, September 1997, 1015-1027

http://www.jci.org

\section{Introduction}

Of the nongraft-versus-host disease $(\mathrm{GVHD})^{1}$ deaths that follow bone marrow transplantation (BMT), $\sim 40 \%$ of the mortality is attributable to idiopathic pneumonia syndrome (IPS). Although the term has been used interchangeably with interstitial pneumonitis, its intended use is for those conditions of respiratory insufficiency and inflammation after BMT for which no microbial agent can be identified (1). IPS accounts for the majority of complications involving the lung in the early postBMT period. Although there is a higher incidence of pulmonary toxicity in humans receiving intense conditioning regimens, these treatments, nevertheless, are beneficial in preventing relapse and promoting BM engraftment in human and rodent studies (2-7). While the risk of developing IPS may be directly related to the degree of pre-BMT conditioning (i.e., chemotherapy, irradiation) and the severity of GVHD after BMT (i.e., allogenicity) $(6,8)$, how allogeneic T cells alter the course of IPS generation in the early post-BMT period have not been examined previously. As the mechanisms responsible for IPS are poorly understood, the aim of this study was to determine the type and degree of lung injury in the early post-BMT period.

Recently, increasing emphasis has been focused on the association of inflammatory cytokines and lung disease that follow BMT. Interstitial pneumonitis and alveolitis have been shown to be correlated with increased levels of TNF $\alpha$ mRNA in the lungs of allogeneic BMT recipient mice, which were partially blocked by anti-TNF $\alpha$ antibody (9). This correlation also has been observed in humans before the development of IPS (10). Other acute proinflammatory cytokines such as IL-1 $\beta$ and IL-6 have been implicated in lung disease models. The intratracheal administration of endotoxin induced IL-1 $\beta$ and IL-6 in addition to TNF $\alpha$, concomitant with the generation of acute lung inflammation (11-13). Neutralization of TNF $\alpha$ or IL-1 $\beta$ with soluble TNF receptor protein and IL-1 receptor antagonist, respectively, inhibited acute inflammation in the lung (12). Studies of bronchoalveolar lavage (BAL) fluids in mice after BMT across minor histocompatible differences demonstrated that increased levels of $\mathrm{TNF} \alpha$ and endotoxin (lipopolysaccharide) at $6 \mathrm{wk}$ after BMT were associated with lung damage and IPS generation (14). The early proinflammatory events in the lung parenchyma which lead to IPS generation after BMT have not been extensively examined.

Among the spectrum of pathological changes seen in pa-

1. Abbreviations used in this paper: BM, bone marrow; BMS, bone marrow plus spleen; BMT, bone marrow transplant(ation); $\mathrm{Cy}, \mathrm{Cy}-$ $\operatorname{toxan}^{\circledR}$ (cyclophosphamide); GVHD, graft-versus-host disease; H\&E, hematoxylin and eosin; IPS, idiopathic pneumonia syndrome; $\mathrm{OH}$ proline, hydroxyproline; P/V, pressure/volume; TBI, total body irradiation; TCD, T cell depleted. 
tients with IPS, fibrotic lung injury is a recurring theme. In the response of the lung to toxic injury, type I epithelial pneumocytes are most sensitive to death from injury and type II cells proliferate to replace them. If the extent of damage to type II cells exceeds the ability for reepithelialization, the deposition of extracellular matrix (collagen) and fibrosis ensues $(15,16)$. Transforming growth factor beta (TGF 3 ) is considered one of the key mediators of the fibrotic process and wound healing $(17,18)$. TGF $\beta$ production in the lung has been associated with collagen formation and pulmonary fibrosis in mice and humans (19-24).

We have focused on the very early proinflammatory and immune-mediated destructive events in the context of a commonly used pre-BMT conditioning regimen (25), consisting of cyclophosphamide $\left(\right.$ Cytoxan $\left.^{\circledR}\right)(\mathrm{Cy})$ and total body irradiation (TBI), and the presence of allogeneic T cells. This regimen was shown previously by this laboratory to be well-tolerated in the early post-BMT period and biologically effective in facilitating alloengraftment (5). Determination of the early proinflammatory events in the lung will aid in the development of strategies to block the development of IPS before the impairment of pulmonary function reaches an irreversible state.

\section{Methods}

Mice. Female B10.BR $\left(\mathrm{H} 2^{\mathrm{k}}\right)$ mice were purchased from The Jackson Laboratory (Bar Harbor, ME) and C57BL/6 $\left(\mathrm{H} 2^{\mathrm{b}}\right)$ were purchased from the National Institutes of Health (Bethesda, MD). Mice were housed in microisolator cages in the SPF facility of the University of Minnesota and cared for according to the Research Animal Resources guidelines of our institution. For BMT, donors were 4-6 wk of age and recipients were used at $8-10 \mathrm{wk}$ of age. Sentinel mice were found to be negative for 15 known murine viruses including those that can contribute to pneumonitis (e.g., CMV, pneumonia virus of mice, K-virus) by our animal facility during repeated extensive evaluations over the study period. In addition, representative mice receiving cytotoxic therapy in combination with immune suppression (i.e., $\mathrm{Cy} / \mathrm{TBI}$ ) were examined and found to have no evidence of viral-induced pathology.

Bone marrow transplant. Our BMT protocol has been described previously (26). Briefly, B10.BR (for allogeneic BMT) or C57BL/6 mice (for syngeneic BMT) were lethally irradiated the day before BMT (7.5 Gray TBI) by x ray at a dose rate of $0.41 \mathrm{cGy} / \mathrm{min}$ as described (27). Donor C57BL/6 BM was T cell depleted (TCD) with anti-Thy $1.2 \mathrm{mAb}$ (clone 30-H-12, rat $\mathrm{IgG} 2_{\mathrm{b}}$, kindly provided by Dr. David Sachs, Massachusetts General Hospital, Boston, MA) plus complement (Nieffenegger Co., Woodland, CA). 30-40 recipient mice per treatment group were transplanted via caudal vein with $20 \times$ $10^{6}$ TCD C57BL/6 (H-2 $)$ marrow with or without $15 \times 10^{6} \mathrm{NK}$ celldepleted (PK136, anti-NK1.1 plus complement) spleen cells (BMS) as a source of GVHD-causing T cells. A parallel set of mice also received Cy (Cytoxan ${ }^{\circledR}$; Bristol Myers Squibb, Seattle, WA) $120 \mathrm{mg} / \mathrm{kg}$ per day as a conditioning regimen pre-BMT on days -3 and -2 . A cohort of mice from each group (eight per group per experiment) was monitored for survival and clinical evidence of GVHD (i.e., body weight, ruffled fur, cachexia, alopecia, and diarrhea). In other experiments, an additional cohort (2-3 mice per group) was studied for lung compliance and total lung capacity (see below).

Lung weights. Mice were killed with sodium pentobarbitol and the thoracic cavity was partially dissected. Lungs were perfused with $1.0 \mathrm{ml}$ saline via the right ventricle of the heart. To maximize use of mice, the left lung (bilobed) was used for weight determinations while the right lung was processed for histopathology (see below). For each mouse, the wet weight was taken immediately after left lung removal from the thorax. Lungs were dried overnight to a constant weight at $80^{\circ} \mathrm{C}$ followed by determination of dry weights. The wet/dry weight ratio was calculated and taken as a measure of the severity of lung injury (28). No correction for extravascular blood content was used in the calculations.

Hydroxyproline (OH-proline) levels. Lungs analyzed for wet/dry weight ratios were also used for $\mathrm{OH}$-proline determinations as a measure of collagen deposition using established procedures (29). Dried lung tissue was hydrolyzed in $6 \mathrm{~N} \mathrm{HCl}$ for $16 \mathrm{~h}$ at $110^{\circ} \mathrm{C}$ under vacuum and total $\mathrm{OH}$-proline content was determined by colorimetric assay based on the oxidation of 4-OH-L-proline to pyrrole and its subsequent reaction with $p$-dimethylaminobenzaldehyde to form a chromaphore that was quantitated by spectrophotometry at an absorbance of $560 \mathrm{~nm}$.

Pressure-volume curves. After full heart-lung excision, the lungs were suspended via the trachea and kept moist with saline. Pressure/ volume $(\mathrm{P} / \mathrm{V})$ curves of air- and liquid-filled lungs were determined according to standard procedures $(30,31)$. Air was delivered into the lungs via a tracheal cannula in $0.05 \mathrm{ml}$ increments with a syringe while measuring intratracheal pressure with a transducer until $25-30 \mathrm{~cm}$ $\mathrm{H}_{2} \mathrm{O}$ pressure was reached (total lung capacity). Air was then withdrawn in $0.05 \mathrm{ml}$ increments until pressure was atmospheric. This was repeated three times and data was procured from the third series. The lungs were then degassed in a vacuum and a series of $3 \mathrm{P} / \mathrm{V}$ loops performed with PBS during which the lungs were completely immersed in PBS. Specific lung compliance was calculated from the slope of the third deflation $\mathrm{P} / \mathrm{V}$ curve from points flanking $5 \mathrm{~cm} \mathrm{H}_{2} \mathrm{O}$ pressure (which is considered normal breathing range) as follows,

\section{$\frac{\Delta \text { Volume } / \Delta \text { Pressure }}{\text { Av volume }}$}

where volume is in milliliters, pressure is in centimeters of $\mathrm{H}_{2} \mathrm{O}$, and Av volume is the average volume over the pressure range used to generate the slope of the $\mathrm{P} / \mathrm{V}$ curve (i.e., $\Delta$ Volume/ $\Delta$ Pressure).

Electron microscopy. Small pieces $\left(2-3 \mathrm{~mm}^{3}\right)$ of lung tissue were fixed in $2 \%$ glutaraldehyde for $1-2 \mathrm{~d}$ at $4^{\circ} \mathrm{C}$ followed by postfixation in $1 \%$ osmium tetroxide (EM Sciences, Fort Washington, PA) in $0.1 \mathrm{M}$ sodium cacodylate buffer for $1 \mathrm{~h}$, dehydrated in graded ethanol and propylene oxide and embedded in Epon 812 (EM Sciences). Sections were cut at a thickness of $600 \mathrm{~nm}$, stained with uranyl acetate/lead citrate (EM Sciences) and examined with a Philips 301 electron microscope.

Frozen tissue preparation. After removal of the left lung for lung weights, the cut bronchus was clamped and a mixture of $0.5 \mathrm{ml}$ optimal cutting temperature medium (OCT; Miles Laboratories Inc., Elkhart, IN)/PBS (3:1) was infused via the trachea into the right lung. The lung, in addition to other GVHD target organs such as the spleen, colon, and liver were arranged in aluminum foil cups, snapfrozen in liquid nitrogen and stored at $-80^{\circ} \mathrm{C}$. Since two separate dissection teams worked on each mouse, lung perfusions, lung separations, dissections, and freezing were achieved in under 8 min per mouse to ensure maximal quality of frozen specimens.

Immunohistochemistry. Frozen sections were cut $4-\mu \mathrm{m}$ thick, mounted onto glass slides, and fixed for $5 \mathrm{~min}$ in acetone. After a blocking step in $10 \%$ normal horse serum (Sigma Chemical Co., St. Louis, MO), immunoperoxidase staining using biotinylated mAbs was performed essentially as described (32) using avidin-biotin blocking reagents, $\mathrm{ABC}$-peroxidase conjugate and $\mathrm{DAB}$ chromogenic substrate purchased from Vector Laboratories, Inc. (Burlingame, CA). The biotinylated mAbs used were as follows: anti-CD3 (clone F500A2), anti-CD4 (clone GK1.5), anti-CD8 (clone 2.43), anti-Mac-1 (clone M1/70), anti-Gr-1 (clone RB6-8C5), anti-I-A ${ }^{\mathrm{k}}$ (clone 11-5.2), anti-I-A ${ }^{\mathrm{b}}$ (clone KH74), anti-B7.1 (clone 1G10), anti-B7.2 (clone GL1), and anti-ICAM-1 (clone 3E2), all purchased from PharMingen (San Diego, CA). Representative sections from each tissue block were stained with hematoxylin and eosin (H\&E) for histopathologic assessment.

The number of positive cells in the lung were quantitated as the percent of nucleated cells at a magnification of $200(20 \times$ objective lens). Four to eight fields per lung were evaluated. 
In situ hybridization. This procedure has been described in detail elsewhere (33). Frozen sections $(4 \mu \mathrm{m})$ were thaw-mounted onto baked glass slides and fixed in 3\% formaldehyde (Fisher Scientific Co., Fairlawn, NJ) for $1 \mathrm{~h}$. After acetylation $(0.25 \%$ acetic anhydride [Fisher Scientific Co.], 0.1 M triethanolamine-HCl, [Boehringer Mannheim Biochemicals, Indianapolis, IN]), sections were hybridized, under a sealed coverslip, overnight at $50^{\circ} \mathrm{C}$ with digoxigenin-labeled antisense RNA probes (transcribed off of bacterial promoter-containing plasmids) complementary to mRNAs of cytokines. The corresponding ribonucleotide sequences used were: 1-1339 for IL-1 $\beta, 1-1110$ for TNF $\alpha$, and 1-985 for TGF $\beta$. Excess riboprobe was removed and tissue sections were washed in preparation for immunological detection of digoxigenin-labeled RNA duplexes with antidigoxigenin antibody (alkaline-phosphatase conjugated; Boehringer Mannheim Biochemicals). After color development, sections were mounted in aqueous medium (Gelmount; Biomeda Corp., Foster City, CA). Positive cells were quantitated as described above.

Serum cytokine level determination. At the time of killing, blood was collected by cardiac puncture, placed immediately at $4^{\circ} \mathrm{C}$, the serum separated at $4^{\circ} \mathrm{C}$ and stored frozen at $-80^{\circ} \mathrm{C}$. Circulating levels of IL- $1 \beta$, IL-6, IFN- $\gamma$, TNF- $\alpha$, and TGF $\beta$ (free and bound) were determined by ELISA using kits (R\&D Systems, Minneapolis, MN) specific for mouse cytokines, except for TGF $\beta$, which was determined using a cross-reacting human TGF $\beta$ kit. For determination of total TGF $\beta$, samples were first acidified with $0.1 \mathrm{~N} \mathrm{HCl}$ to release bound TGF $\beta$ from its latent form.

Statistical analysis. Kaplan-Meier plots of survival data were analyzed by Mantel-Peto-Cox summary of Chi square (34). Other data were analyzed using a Student's $t$ test. Probability $(P)$ values $\leq 0.05$ were considered statistically significant. Correlation coefficient determinations were done using MS Excel 5.0 ${ }^{\mathrm{TM}}$ statistical software.

\section{Results}

Acceleration of IPS, GVHD, and lethality by $C y$. Since the majority of BMT protocols in humans entail the use of $\mathrm{Cy}$ and TBI as a preconditioning regimen, experiments were set up to compare the effects of the combined regimen with TBI alone. The dose of Cy used (120 mg/kg per day for $2 \mathrm{~d}$ ) was previously shown by this laboratory (5) to be well-tolerated in the early post-BMT period and biologically effective in facilitating the engraftment of TCD allogeneic BM when combined with 7.5 Gray TBI. For these reasons, the same Cy/TBI dose schedule was maintained for relevance to the study of IPS. Fig. $1 A$ (survival) and $B$ (body weights) illustrate the outcome of a prototypic experiment for our established allogeneic GVHD mouse model. Similar outcomes have been obtained in three separate allogeneic model systems (not shown). B10.BR $\left(\mathrm{H} 2^{\mathrm{k}}\right)$ recipient mice were irradiated with 7.5 Gy TBI on day -1 and transplanted on day 0 with $\mathrm{C} 57 \mathrm{BL} / 6\left(\mathrm{H} 2^{\mathrm{b}}\right) \mathrm{BM}$ with or without spleen cells (BMS) as a source of GVHD-causing T cells. The addition of Cy (120 mg/kg per day) on days -3 and -2 as a conditioning regimen pre-BMT significantly accelerated mortality $(P<0.0001)$ compared to the GVHD control group (BMS). These early GVHD-induced deaths, accelerated by $\mathrm{Cy}$, were dependent on the presence of allogeneic $\mathrm{T}$ cells since recipients of syngeneic BMS given Cy exhibited 100\% survival in the same post-BMT period (not shown).

H\&E staining of cryosections of lungs removed on day 7 after BMT (Fig. 2) show some edema of adventitial space with variable cellular infiltration and interstitial thickening with decreased alveolar septal size in mice receiving Cy/TBI. Since these changes were interspersed with normal appearing lung tissue, these findings are equivalent to grade 2 (out of 8) lung fibrosis (35). Evidence of mononuclear cell adhesion and dia-

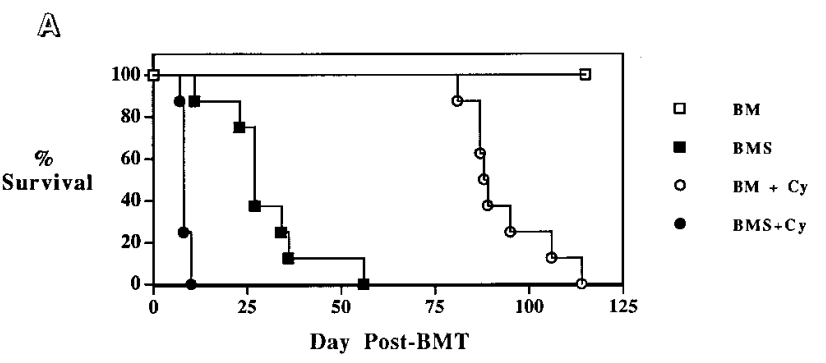

回

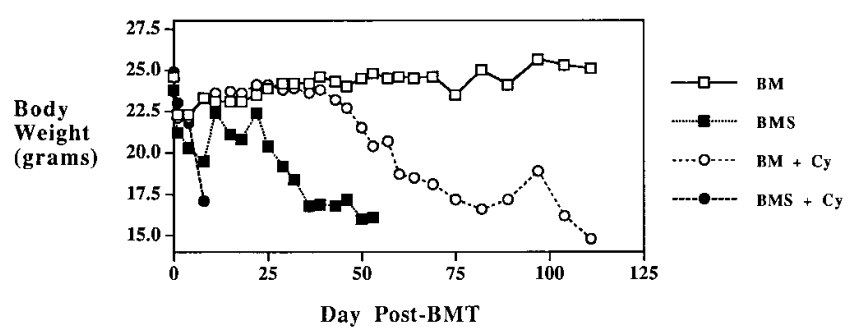

Figure 1. Acceleration of mortality $(A)$ and weight loss $(B)$ by Cy after allogeneic BMT. B10.BR recipient mice ( $n=8$ per group) were lethally irradiated $(7.5 \mathrm{~Gy})$ on day -1 and infused on day 0 with C57BL/6 BM either with BMS or without spleen cells as indicated. Groups treated with Cy received $120 \mathrm{mg} / \mathrm{kg}$ per day on days -3 and -2 . The BMS + Cy group exhibited an accelerated mortality $(P<$ 0.0001 ) compared to the BMS group.

pedesis through the vasculature was seen in the lungs of mice receiving BMS that was amplified by $\mathrm{Cy}$ resulting in perivascular infiltrates with thickness of 1-3 cells resembling mild acute rejection that could be given a score between grades 1 and 2 (36). Mice receiving $\mathrm{Cy} / \mathrm{TBI}$ and BMS that survived to days 10-14 after BMT exhibited increased lung pathology, while TBI mice given BMS exhibited increased pathology as they neared the moribund state at days 25-50 post-BMT (not shown). To document earlier lung changes, lungs taken on day 3 after transplant were evaluated by light and electron microscopy. Although histologic changes were not identifiable by light microscopy on day 3 after BMT (not shown), electron microscopy revealed that changes were, in fact, evident at this early time point. Fig. 3, $A$ and $C$ reveal some minor edema of endothelium attributable to the irradiation regardless of whether $\mathrm{T}$ cells were given in the inoculum. The addition of $\mathrm{Cy}$, in general, caused more edema and blebbing of epithelial and endothelial cells in a focal, rather than a diffuse, pattern (Fig. $3 \mathrm{~B}$ ). As expected, the most severe injury was seen in the BMS group given Cy plus TBI (Fig. $3 \mathrm{D}$ ). The lungs of these mice exhibited increased cellularity with areas of lung tissue destruction and exudation of proteinaceous debris. Again, this was in a focal pattern that was interspersed with areas of normal appearing lung tissue. These histologic findings of pulmonary injury with congestion and focal inflammatory infiltrates are consistent with the generation of IPS in our model and may be described as early diffuse alveolar damage fitting the pattern of IPS histopathology seen in patients. IPS was potentiated by $\mathrm{Cy}$ and accelerated by allogeneic $\mathrm{T}$ cells.

Cy also caused a late-induced lethality in mice receiving TCD BM only (Fig. $1 A, P<0.0001$ compared to TCD BM 


\section{- Cytoxan}
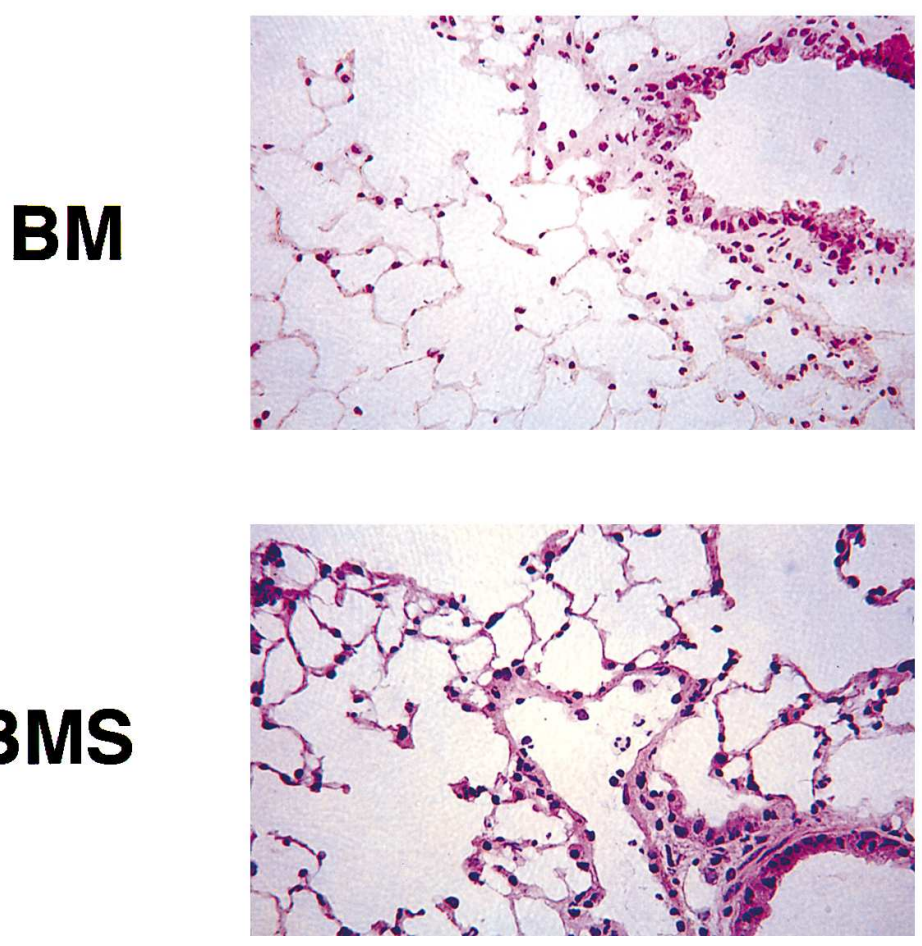

\section{+ Cytoxan}

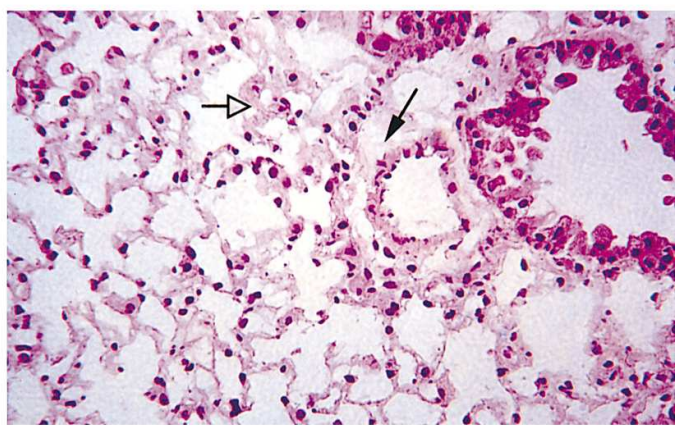

Figure 2. Histologic assessment of pulmonary fibrosis and inflammation on day 7 after allogeneic BMT. H\&E stained frozen sections of lungs taken from the indicated treatment groups reveal the presence of edema of the adventitial space (solid arrow) and interstitial thickening (open arrow) in Cy treated mice equivalent to grade 2 fibrosis. Mice receiving BMS exhibited mononuclear cell adhesion and diapedesis through the vasculature resulting in perivascular and peribronchiolar infiltrates similar to grades $1-2$ mild acute rejection. $(\times 100$; Resolution power, 40× objective lens).

recipients without $\mathrm{Cy}$ ). These data are consistent with a clinical course of Cy-induced pulmonary toxicity. However, histologic assessment of GVHD target organs from these lateinduced deaths revealed an inflammatory process localized mainly to the basal layers of the small intestine with no involvement of the colon and only mild mononuclear cell infiltration in the lung. This is in contrast to early post-BMT deaths that had overt signs of GVHD-mediated colitis, as well as acute mononuclear cell infiltration with tissue injury, into the liver, lung, skin, pancreas, kidney, and spleen. Mice dying of late-induced toxicity did not exhibit evidence of BM aplasia since hematocrit values at $6 \mathrm{wk}$ after BMT were not affected by Cy (46.8 \pm 1.8 versus $46.0 \pm 3.0$, eight mice per group). Although this late toxicity of $\mathrm{Cy}$ is not the focus of this study, from the histologic assessment and the prolonged lag-phase between weight loss and mortality, it is speculated that these mice may be dying of a malabsorption problem that may be enhanced by insufficient food intake because of incisor tooth abnormalities caused by $\mathrm{Cy}$ in rodents but not humans $(37,38)$.

$C y$ and $T$ cell-induced lung injury after BMT manifests as physiological derangement rather than barrier disruption. To determine whether the lung injury induced in the early postBMT period involved a disruption in the blood-gas barrier, and therefore edema, the wet/dry weight ratios were calculated (Table I). The data of Table I, representative of four experiments, show that wet/dry ratios did not differ significantly among the treatment groups, even when the data were pooled according to whether the mice were given Cy or not. Since this ratio does not always reflect lung injury because of differences in cellularity (28), we compared wet lung weights alone and dry weights alone among the groups from days -2 to +10 (data for time points before day 7 not shown). Increased wet weights began to appear on day 7 in all groups, although there was a high degree of variability and statistical significance was

Table I. Lung Weights and Wet/Dry Weight Ratios After Allogeneic BMT

\begin{tabular}{|c|c|c|c|c|c|c|}
\hline \multirow[b]{2}{*}{ Group* } & \multicolumn{3}{|c|}{ Day 7} & \multicolumn{3}{|c|}{ Day 10} \\
\hline & $\begin{array}{l}\text { Wet/dry } \\
\text { ratio }\end{array}$ & $\begin{array}{l}\text { Wet } \\
(\mathrm{mg})\end{array}$ & $\begin{array}{c}\text { Dry } \\
(\mathrm{mg})\end{array}$ & $\begin{array}{c}\text { Wet/dry } \\
\text { ratio }\end{array}$ & $\begin{array}{l}\text { Wet } \\
(\mathrm{mg})\end{array}$ & $\begin{array}{c}\text { Dry } \\
(\mathrm{mg})\end{array}$ \\
\hline $\mathrm{BM}$ & $5.08 \pm 0.96(9)$ & $71 \pm 30$ & $14 \pm 5$ & $5.01 \pm 0.39(8)$ & $75 \pm 11$ & $15 \pm 2$ \\
\hline BMS & $4.92 \pm 0.59(11)$ & $77 \pm 22$ & $17 \pm 4^{\ddagger}$ & $5.34 \pm 0.35(8)$ & $83 \pm 6^{\ddagger}$ & $15 \pm 1$ \\
\hline $\mathrm{BM}+\mathrm{Cy}$ & $5.00 \pm 0.52(9)$ & $78 \pm 27$ & $15 \pm 4$ & $5.64 \pm 0.99(5)$ & $76 \pm 8$ & $14 \pm 2$ \\
\hline $\mathrm{BMS}+\mathrm{Cy}$ & $4.99 \pm 0.39(9)$ & $74 \pm 25$ & $16 \pm 4^{\ddagger}$ & $5.18 \pm 1.18(6)$ & $94 \pm 16^{+}$ & $18 \pm 2^{\S}$ \\
\hline Controls & $4.91 \pm 0.48(8)$ & $64 \pm 10$ & $13 \pm 2$ & & & \\
\hline
\end{tabular}

*B10.BR recipient mice were given Cy $120 \mathrm{mg} / \mathrm{kg}$ per day on days -3 and -2 , if indicated, lethally irradiated on day -1 and infused with C57BL/6 BM either with BMS or without spleen cells as described in Methods. Numbers in brackets indicate number of mice in group. Four experiments are represented. ${ }^{\ddagger} P<0.05$ versus control age-matched B10.BR mice. ${ }^{\S} P<0.001$ versus control age-matched B10.BR mice. 

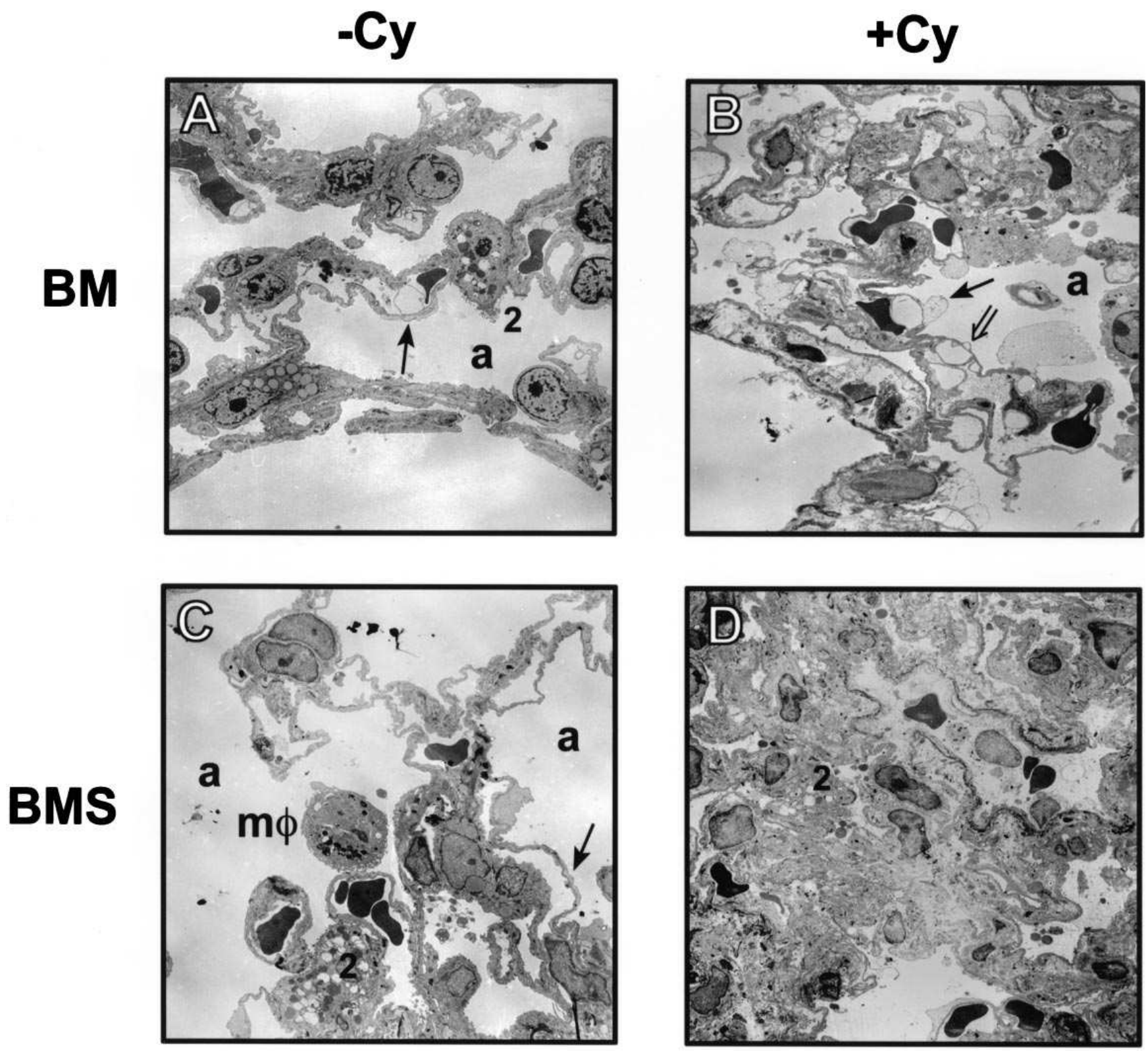

Figure 3. Electron microscopic evaluation of lungs taken on day 3 after BMT showing small amounts of edema and endothelial blebbing (solid arrows) in all groups. Epithelial cell splitting (open arrow) was seen in Cy/TBI-treated mice. Necrosis and exudation of proteinaceous debris was seen most frequently in the Cy/TBI BMS group $(D)$ although in a focal pattern interspersed with normal appearing lung tissue. Sections were cut at $600 \mathrm{~nm}$ and stained with uranyl acetate/lead citrate. Salient features and treatment groups are indicated. $a$, alveolar space; 2 , type II epithelial cell; $m \varnothing$, macrophage. $\times 4,200$.

achieved only in TBI or Cy/TBI BMS mice $(P<0.001)$ that survived until at least day 10 . With respect to dry weights, values diverged at day 7 after BMT for mice receiving splenic $\mathrm{T}$ cells $(P<0.05)$ regardless of whether the mice received $\mathrm{Cy}$. These data suggest that Cy conditioning does not significantly increase the wet weight (because of increased cellularity and edema) or dry weight (because of cells, proteinaceous debris, or extracellular matrix deposition) in our model. Evidence of barrier injury seen by electron microscopy on day 3 was not of sufficient magnitude or frequency to be detected by lung weight measurements at this time point.

To assess other physiological changes in the lung induced by the conditioning regimens and BMT, we measured total lung capacity and compliance. Fig. 4 shows the deflation limbs of the $\mathrm{P} / \mathrm{V}$ loops of lungs taken from representative experimental animals on day 7 after BMT compared to a control $\mathrm{P} / \mathrm{V}$ range generated from five unmanipulated mice (gray). The summary and statistical evaluation of data from three experiments for specific compliance in air and saline and total lung capacity are shown in Table II. Specific compliance in air was decreased for mice receiving BMS ( $P<0.05$ versus normals) regardless of whether they received $\mathrm{Cy}$. In fact, comparison of groups receiving $\mathrm{T}$ cells versus those that did not was highly significant $(P=0.005)$. In contrast, comparison of groups according to whether they received $\mathrm{Cy}$ or not was not significantly different $(P=0.97)$. A statistically significant difference 


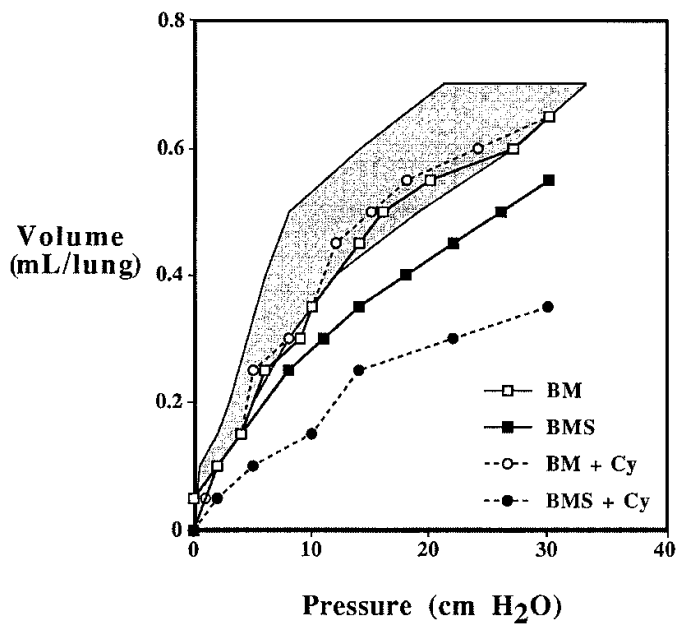

Figure 4. Deflation limbs of $\mathrm{P} / \mathrm{V}$ loops of lungs of experimental mice from day 7 after BMT compared to control P/V range (gray shading) generated from 5 age-matched control mice. Curves of representative mice from experimental groups were shifted down and to the right and statistical significance was achieved with mice given BMS regardless of whether they received Cy. See Table II for data summary.

$(P<0.05)$ was found in the decreased specific compliance when saline was used to fill the lungs only in $\mathrm{Cy} / \mathrm{TBI}$ mice receiving BMS. When compliance is measured in this way, alveolar surface tension effects are eliminated, suggesting that in $\mathrm{Cy} / \mathrm{TBI}$ BMS recipients there were alterations in tissue elastic recoil (possibly due to increased elastin and collagen deposition). In summary, the presence of donor splenic $\mathrm{T}$ cells was the major determinant of a decrease in lung compliance, and changes in surface tension (i.e., alveolar surfactant level and function) may have been contributing factors. In addition, Cy/TBI treatment, but only in combination with allogeneic $\mathrm{T}$ cells, precipitated a decrease in the tissue elastic recoil properties of the lungs.

The decrease in total lung capacity was most pronounced for groups receiving TBI or Cytoxan/TBI with BMS $(P<0.01)$ that could compound the respiratory insufficiency already seen in these groups. Mice receiving Cy but no splenic $\mathrm{T}$ cells also differed from controls but to a lesser degree of significance $(P<0.05)$. These data imply that immune-mediated mechanisms may be stronger determinants of early post-BMT pulmonary dysfunction as compared to $\mathrm{Cy} / \mathrm{TBI}$ conditioning regimens.

To determine the extent to which the lung injury induced was fibrotic, lung $\mathrm{OH}$-proline levels were measured as an index of collagen deposition. No dramatic changes in OH-proline levels were caused by any of the treatments in allogeneic transplants at any time point before or after BMT, even as long as 3 mo after BMT in either allogeneic or syngeneic recipients (not shown). The histologic data indicate that our model induces a congestive-type of lung injury with phases of acute inflammation resembling rejection, but not fibrosis, at the time points studied.

Early cellular events lead to IPS. To begin to understand how Cy and allogeneic T cells contribute to IPS generation, the early cellular and proinflammatory processes (see below) were analyzed in recipients during the peri-BMT period. Immunoperoxidase stains of TBI BMS recipient lungs from day 7
Table II. Comparisons of Specific Lung Compliance and Total Lung Capacity in Mice After Allogeneic BMT

\begin{tabular}{llll}
\hline \multirow{2}{*}{ Group } & \multicolumn{1}{c}{ Specific compliance $\left(1 / \mathrm{cm} \mathrm{H}_{2} \mathrm{O}\right.$ pressure $)$} & \multicolumn{1}{c}{$\begin{array}{c}\text { Total lung } \\
\text { capacity }(\mathrm{ml})\end{array}$} \\
\cline { 2 - 3 } & \multicolumn{1}{c}{ Air } & \multicolumn{1}{c}{ Saline } & \\
BM & $0.129 \pm 0.032(7)$ & $0.652 \pm 0.389(5)$ & $0.521 \pm 0.189(7)$ \\
BMS & $0.115 \pm 0.036(7)^{*}$ & $0.757 \pm 0.391(5)$ & $0.500 \pm 0.091(7)^{\ddagger}$ \\
BM + Cy & $0.132 \pm 0.034(7)$ & $0.462 \pm 0.082(5)$ & $0.471 \pm 0.191(7)^{*}$ \\
BMS + Cy & $0.098 \pm 0.027(6)^{*}$ & $0.310 \pm 0.111(4)^{*}$ & $0.420 \pm 0.160(6)^{\ddagger}$ \\
Control & $0.149 \pm 0.036(6)$ & $0.505 \pm 0.141(6)$ & $0.687 \pm 0.096(6)$
\end{tabular}

Lungs were excised en bloc with the heart from mice on day 7 after BMT and P/V loops performed as described. Numbers in brackets indicate number of mice in group. Three experiments are represented. $* P<$ 0.05 compared to age-matched normal control mice. ${ }^{\ddagger} P<0.01$ compared to age-matched normal control mice.

after BMT revealed increased frequencies of $\mathrm{CD} 3$ positive $\mathrm{T}$ cells $\left(\mathrm{CD}^{+}\right.$and $\left.\mathrm{CD}^{+}\right)$in perivascular, peribronchiolar, and interstitial locations accompanied by increases in Mac-1 positive cells (Fig. $5 A$ ). These increases were not seen in recipients of allogeneic BM only or syngeneic controls (Fig. $5 \mathrm{~B}$ ). The Mac-1 positive component was comprised mostly of monocyte/ macrophage lineage cells since fewer Gr-1+ neutrophils were seen, albeit in higher frequency than seen in normal lung. Interestingly, the Mac-1 positive cells were of host origin (Fig. 5). Because there was an intense staining for B7-1 at the sites of increased Mac-1 positive cells, the colocalization of $\mathrm{T}$ cells and macrophages sets the stage for antigen presentation to and costimulation of allogeneic $\mathrm{T}$ cells in the lung. This situation was virtually absent in syngeneic controls (Fig. $5 \mathrm{~B}$ ). Thus, a critical feature of the early cellular events associated with IPS generation are the abundance of host monocytes/macrophage lineage cells, juxtaposed to $\mathrm{T}$ cells, providing evidence that the conditions for alloresponse in the lung may be conducive to the subsequent development of IPS.

T cells are responsible for enhancement of lung macrophage activity. Since T cells and macrophages were colocalized in the lung, we wanted to determine whether the addition of allogeneic $\mathrm{T}$ cells to the $\mathrm{BM}$ inoculum affected the lung macrophage population. Fig. $6 A$ shows that on day -1 (lungs were taken $2 \mathrm{~h}$ after irradiation), the initial tissue damage due to irradiation caused a moderate increase in total lung Mac-1 positive cells ( $P=0.08$ versus normals) which was enhanced by Cy $(P=$ 0.019 versus normals). In the post-BMT period, the numbers of macrophages did not continue to increase significantly unless allogeneic $\mathrm{T}$ cells were given as part of the BM inoculum (Fig. $6 \mathrm{~A}$, day $7, P=0.0026$ versus $\mathrm{BM}$ only groups). These macrophages were of host origin $\left(\mathrm{IA}^{\mathrm{k}}\right)$ as demonstrated by immunohistochemical staining with $\mathrm{mAbs}$ to MHC class II. No donor class II was observed in the lungs of any treatment group at this time although both host and donor MHC class II were present in the spleens of all mice. As an additional control on the effects of the BMS inoculum, donor cells were given to allogeneic recipients without TBI or $\mathrm{Cy}$ and were rejected by day 3 after injection as evidenced by lack of staining for donor positive cells in the spleen (not shown). Also, for this control group, no increases in host monocytes, or MHC class II were seen in the lungs on days 3 or 7 after injection (not shown) compared to either unmanipulated mice or syngeneic 

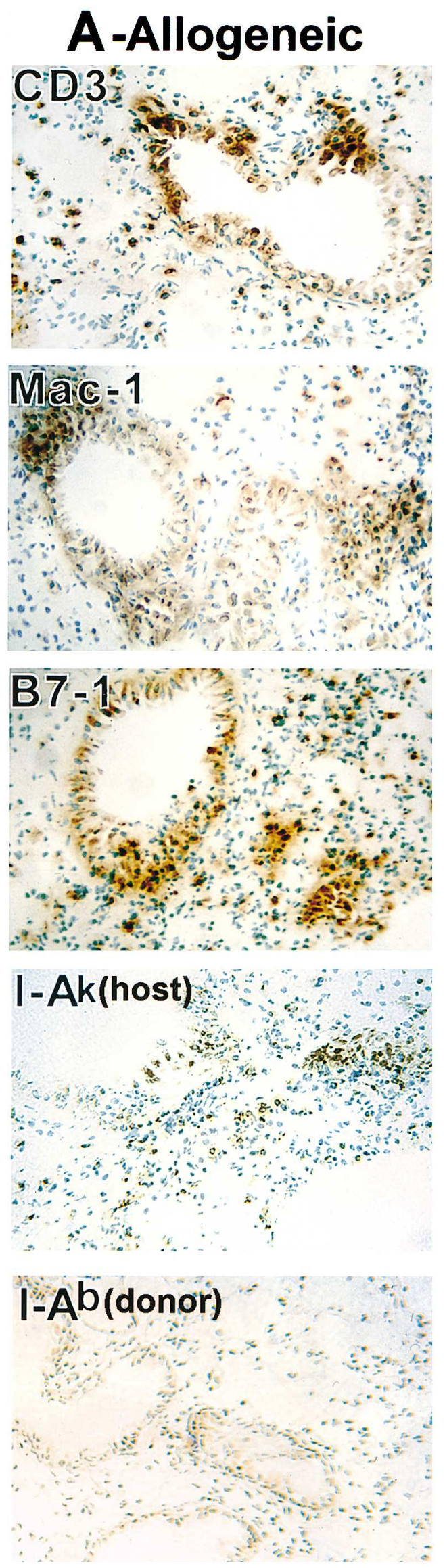
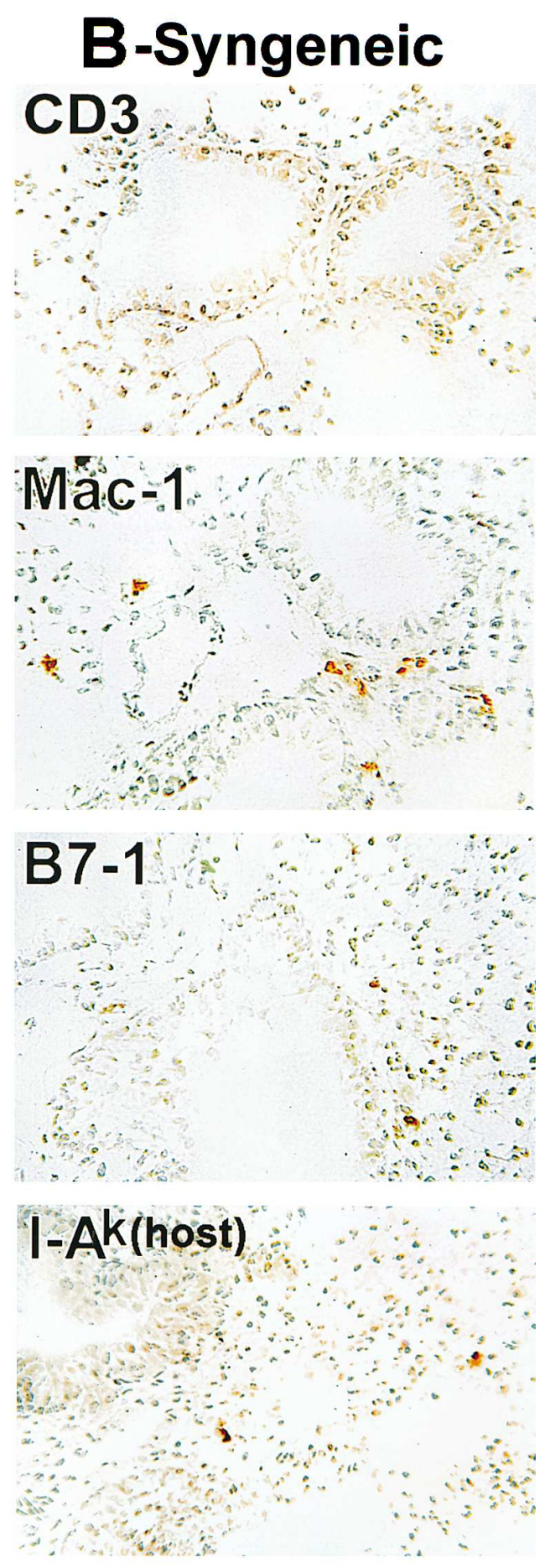

Figure 5. Characterization of lung infiltrates by immunoperoxidase staining of lungs of TBI conditioned recipients given BMS. Lung tissues were taken on day 7 after BMT from allogeneic $(A)$ and syngeneic $(B)$ B10.BR recipients given C57BL/6 or B10.BR donor cells, respectively. Frozen sections were incubated with biotinylated $\mathrm{mAbs}$ with specificities as indicated and developed with peroxidase-conjugated avidin-biotin complex and DAB chromogen (methyl green counterstain). $\times 100$, resolution power equivalent to $40 \times$ objective lens. 


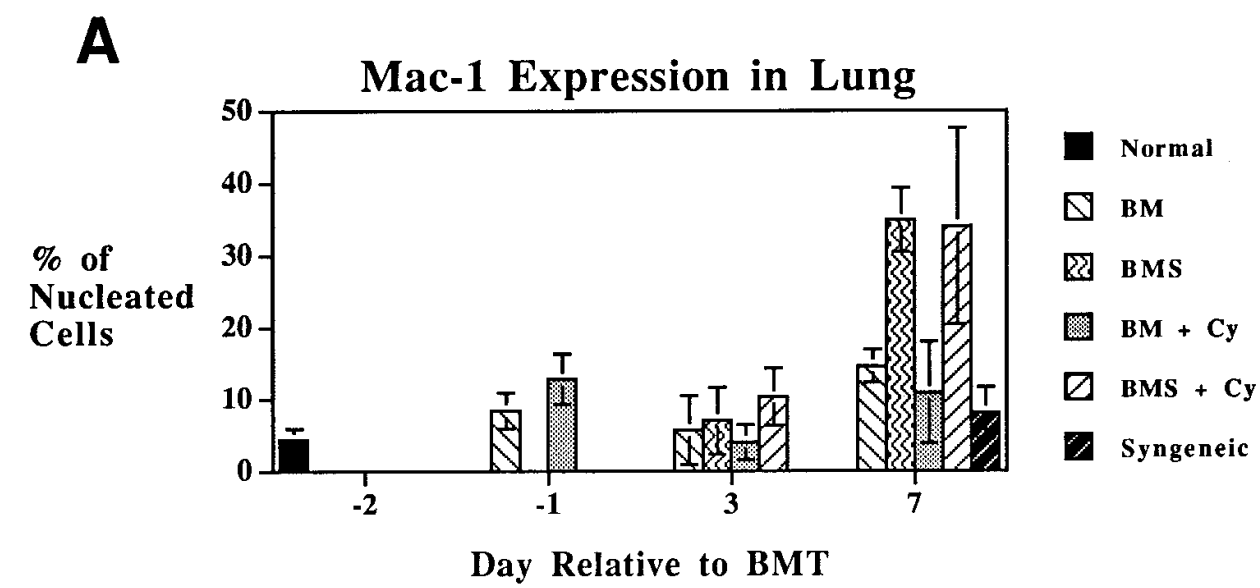

B

Host MHC Class II Expression in Lung

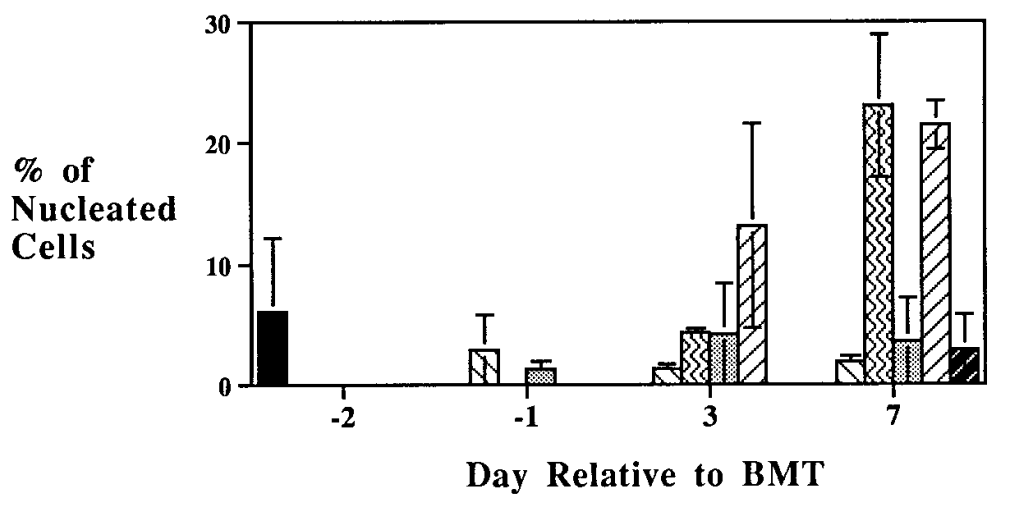

Figure 6. Expression of Mac-1 $(A)$ and host MHC Class II $(B)$ as determined by immunoperoxidase staining with biotinylated $\mathrm{mAbs}$. B10.BR recipient mice were preconditioned with TBI (day -1$)$ with or without Cy (days $-3,-2)$ as indicated and given C57BL/6 bone marrow alone or with spleen cells $(B M S)$ on the day of BMT (day 0 ). Lung tissues were harvested on days $-1,+3$, and +7 relative to the day of BMT. Data are expressed as the percent of nucleated cells expressing Mac-1 or host MHC class II in the lung as determined by counting 4-9 fields per lung section under light microscope. Normal control levels are indicated by solid black bars. Mean values \pm SD are indicated for 2-3 mice per group per time point from two representative experiments. Staining for donor MHC Class II at these time points in the lung was negative for all groups. transplant controls. The number of host MHC class II-expressing cells in the lung was increased significantly in mice receiving TBI and allogeneic BMS (Fig. $6 B, P=0.0001$ versus BM only groups on day 7). Cy/TBI treatment appeared to accelerate this increase but only in the presence of donor T cells (on day 3, $P=0.1$ versus BMS without $\mathrm{Cy}$ ). This increase in MHC class II was accompanied by the expression of the $\mathrm{T}$ cell costimulatory molecules B7-1 and B7-2 (Fig. 7, correlation coefficients $r^{2}=0.82$ and 0.77 , respectively). B7- 1 was the predominant B7 molecule expressed in the lung (see Figs. 5 and 7). The expression of B7-1 was highest in mice receiving allogeneic $\mathrm{T}$ cells and was rarely seen in syngeneic controls, lending further support for the importance of immune-responsive elements in the initial phase of IPS generation in our mouse model.

Cy increases the frequency of TGF $\beta$-transcribing cells in the lung while T cells are responsible for increased systemic levels of IL-6, IFN $\gamma$, and TNF $\alpha$. In situ hybridization was performed to determine whether proinflammatory cytokine mRNA was induced at the time of cellular infiltration. Analysis of cytokine mRNA expression on day 7 after BMT revealed the presence of a low (but higher than normal) frequency of cells $(<1 \%$ of nucleated cells) transcribing mRNA for the inflammatory cytokines IL-1 $\beta$ and TNF $\alpha$ in TBI BMS mice (not shown). This frequency was not increased by Cy treatment but cells transcribing these mRNAs were seen earlier post-BMT (day 3) in Cy/TBI BMS recipients. By far, the most frequently seen cytokine-transcribing cell was that for $\mathrm{TGF}_{1}$, the frequency and intensity of which was higher in TBI BMS mice (Fig. $8 a$ ) than in normal non-BMT controls (Fig. $8 d$ ). Staining frequency and intensity for TGF $\beta$ was increased if $\mathrm{Cy}$ was included with the conditioning regimen (Fig. 8, $b$ and $c$ ). TGF $\beta$ production was seen in cells surrounding the vasculature, cells in the lung parenchyma and also in bronchiolar epithelial cells (see Fig. 8, $a-c$ ). Fig. 9 shows that the frequency of TGF $\beta$-transcribing cells was increased early in Cy/TBI treated groups $(P=0.019$ versus TBI, day -1$)$ and then dropped to normal levels by day 7 . For mice not receiving $\mathrm{Cy}$, the frequency of TGF $\beta$ mRNA positive cells was increased only in mice receiving BMS ( $P=0.01$ versus BM only group) and was not seen at high levels until day 7 after BMT. In mice not receiving either Cy or TBI, the injection of allogeneic BMS cells was found to not affect the frequency of TGF $\beta$ mRNA positive cells in the lung (not shown). Since cytokines present in the circulation, in addition to those produced in situ in the lung, may affect cellular activation and function, we determined the serum levels of the inflammatory cytokines IL- $1 \beta$, IL-6, IFN $\gamma, \mathrm{TNF} \alpha$, and TGF $\beta$ on day 7 after BMT. The data presented in Table III show that the presence of T cells in the BMT inoculum was responsible for increased levels of IL-6, IFN $\gamma$, and TNF $\alpha$. Groups receiving Cy had the highest serum levels of IL-1 $\beta$ and free TGF $\beta$. 


\section{Host I-A vs B7 Expression in Lung}
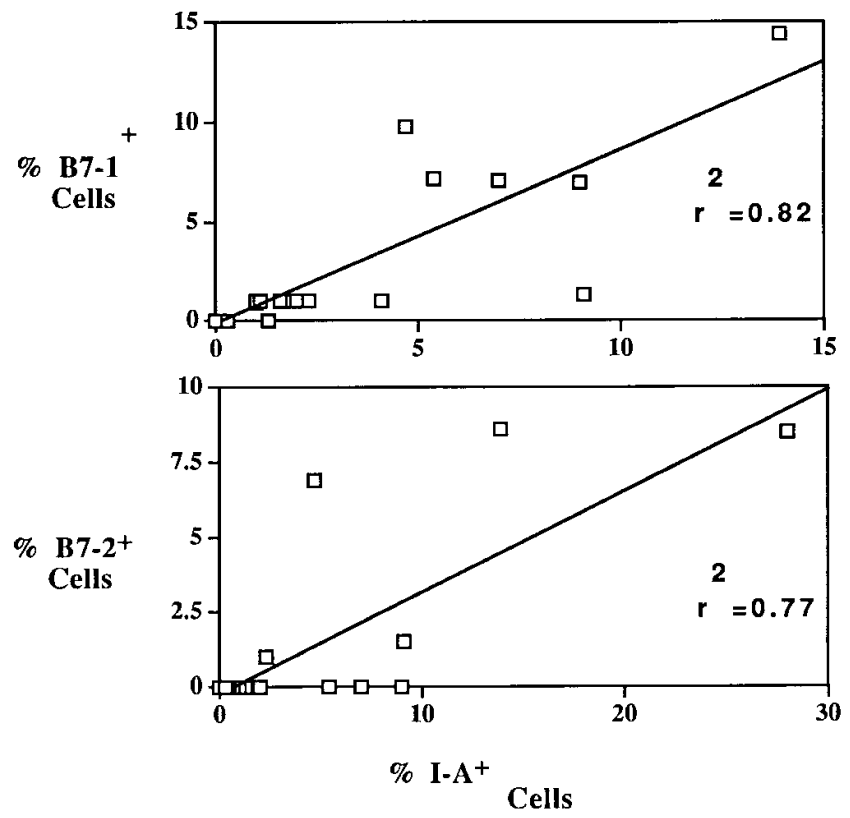

Figure 7. Correlation of host MHC Class II expression with B7-1 and B7-2 across all groups and all time points. The frequencies of positive cells were determined by counting $4-9$ fields per lung section under light microscope ( $20 \times$ objective lens). Correlation coefficients ( $r^{2}$ values) are shown.

\section{Discussion}

We have focused on the critical early proinflammatory events occurring in the peri-BMT period that may promote the generation of IPS. The early phases of IPS induction in our murine model were associated with an increase in the lung host macrophage population, upregulation of $\mathrm{T}$ cell costimulatory ligands and induction of inflammatory proteins conducive to the recruitment and activation of macrophages. The presence of costimulatory molecules such as host MHC class II, B7-1 and B7-2, implicate these lung macrophages as likely mediators of antigen presentation and costimulation of the donor $\mathrm{T}$ cells colocalized with them. Frequencies of cells transcribing the inflammatory proteins TNF- $\alpha$, IL- $1 \beta$, and especially TGF $\beta$ were increased as assessed by in situ hybridization. Cy accelerated this cellular and cytokine cascade. Because the exacerbation of macrophage activation and severity of IPS was depen- dent on allogeneic $\mathrm{T}$ cells, our data strongly imply that the immune system plays a critical role in the pulmonary events leading to IPS generation. Importantly, the fact that significant lung injury is present in the peri-BMT period emphasizes the need for very early therapeutic intervention before the damage of IPS becomes profound and irreversible.

The presence of increased numbers of host macrophages in the damaged lung tissue in the peri-BMT period could have important implications for understanding the etiopathogenesis and for designing therapeutic modalities that will affect IPS development. It is not clear whether the host macrophages are being recruited to the lung or are proliferating in situ. The in situ proliferation of lung macrophages after damage induced by bleomycin and hyperoxia in hamsters (39) as well as an increase in the proportion of proliferating macrophages in chronic lung inflammation in humans (40) have been demonstrated. Conversely, the migration of inflammatory cells through the vasculature into the lung induced proliferation of type II cells in the absence of morphological injury to the lung (41). Studies of the response to intratracheal antigen challenge in mice demonstrated that the recruitment of inflammatory cells into lung parenchyma and alveoli was dependent on $\mathrm{CD} 4^{+} \mathrm{T}$ cells, underlining the importance of antigen-driven responses in amplifying the inflammatory response (42). The expression of a monocyte chemotactic factor, RANTES, resulted in the recruitment of monocytes to the lung as evidenced by perivascular cuffing (43). This histological feature was also seen in this study.

These two mechanisms (recruitment and in situ proliferation) resulting in increased host lung monocytes may not be mutually exclusive. However, we favor the former for several reasons. First, lung macrophages were increased as early as $2 \mathrm{~h}$ after TBI which would be insufficient time for in situ proliferation. Second, conditioning with TBI would have all but eliminated the proliferative capacity of the host monocytes. Third, an increased frequency of cells expressing mRNA for TGF 3 , a known chemoattractant for monocytes, implicates this molecule as responsible at least in part for the observed recruitment in macrophages $(44,45$; for review see 46$)$. In this study, mice analyzed in the early post-BMT period exhibited a marked increase in the frequency and staining intensity (i.e., mRNA copy number) of TGF $\beta$-producing cells that was further accelerated by $\mathrm{Cy}$, even in the period immediately preceding BMT. This is consistent with previous findings of the early induction of monocyte chemotactic factors in the lung by $\mathrm{Cy}$ in rats (47). Thus, the damage caused by the metabolic products of $\mathrm{Cy}$ causes an increase in the monocyte chemotactic potential of

Table III. Serum Cytokine Level Determinations*

\begin{tabular}{lcccrrr}
\hline \multicolumn{1}{c}{ Group } & IFN- $\gamma$ & TNF- $\alpha$ & IL-1 $\beta$ & IL- 6 & ${\text { Free TGF } \beta^{\ddagger}}^{\text {Total TGF } \beta^{\ddagger}}$ \\
\hline BM & $2.9 \pm 2.8$ & $5.3 \pm 7.3$ & $1.3 \pm 1.9$ & $32.3 \pm 15.4$ & $2.7 \pm 3.6$ & $2119 \pm 2200$ \\
BMS & $440.2 \pm 160.5^{\S}$ & $52.1 \pm 39.2^{\S}$ & $5.4 \pm 4.5$ & $107.2 \pm 69.4^{\S}$ & $8.7 \pm 15.4$ & $6235 \pm 5989$ \\
BM + Cy & $0.8 \pm 0.7$ & $2.1 \pm 0.9$ & $32.0 \pm 24.1^{\S}$ & $58.1 \pm 17.7^{\S}$ & $44.8 \pm 38.2$ & $7451 \pm 3248$ \\
BMS + Cy & $151.7 \pm 114.1^{\S}$ & $56.0 \pm 31.5^{\S}$ & $18.6 \pm 10.5^{\S}$ & $102.9 \pm 59.9^{\S}$ & $32.1 \pm 17.9$ & $4887 \pm 2659$ \\
Control & $2.5 \pm 2.9$ & $2.8 \pm 5.6$ & $3.5 \pm 2.4$ & $18.0 \pm 4.7$ & $33.0 \pm 23.7$ & $27612 \pm 10649$ \\
& & & & &
\end{tabular}

* All cytokine levels are in $\mathrm{pg} / \mathrm{ml} \pm \mathrm{SD}$ and determined from serum taken on day 7 after BMT, four mice per group (pooled data from two experiments are shown). ${ }^{*}$ Free TGF $\beta$ is determined from nontreated serum whereas total TGF $\beta$ is determined after acidification with $\mathrm{HCl}$, according to manufacturer's directions, to release TGF $\beta$ from its latency associated peptide. ${ }^{\S} P<0.05$ compared to age-matched normal control mice. 

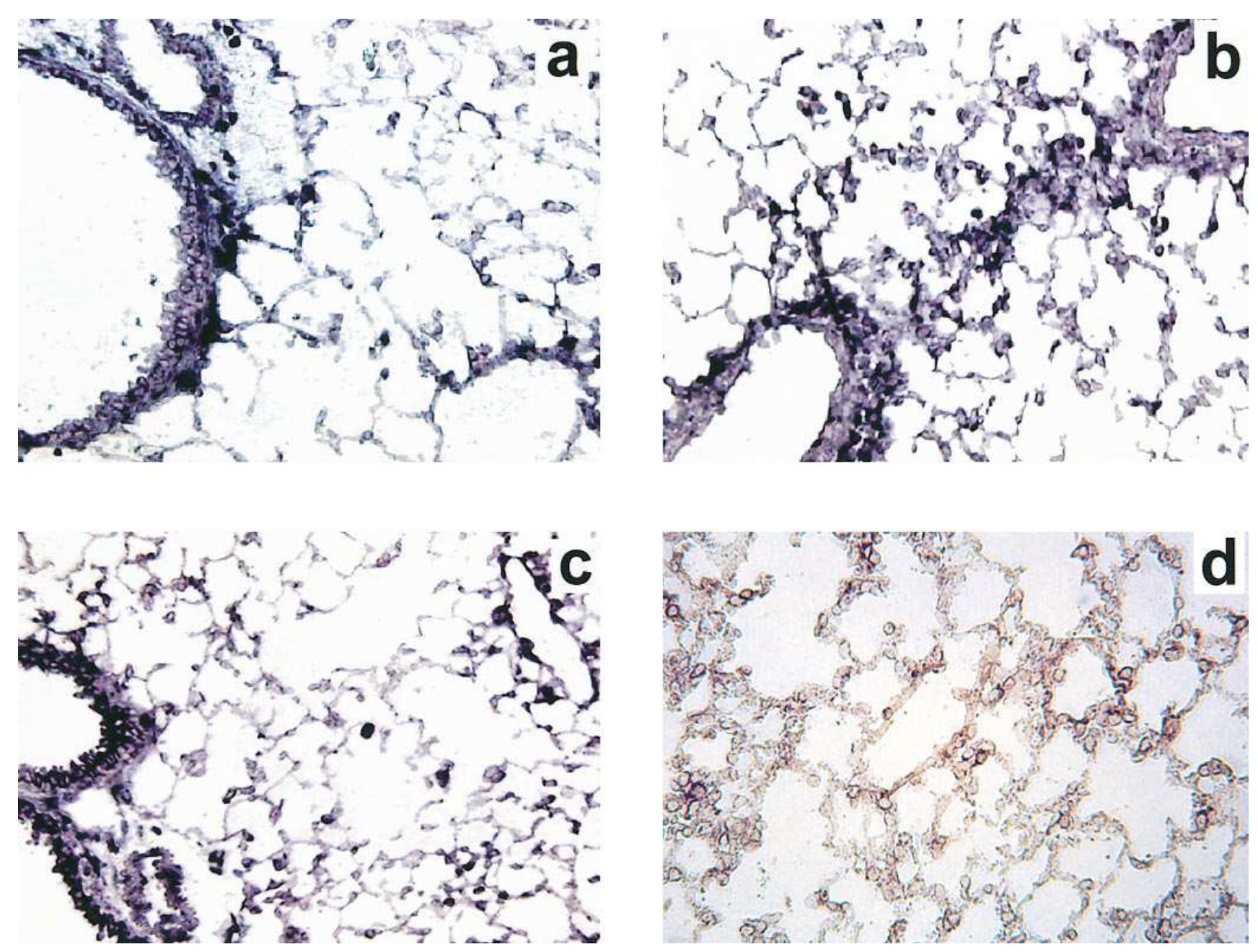

Figure 8. In situ hybridization using antisense digoxigenin-labeled riboprobes for TGF $\beta$ mRNA on day 7 after allogeneic BMT of TBI BMS recipients $(a)$, Cy/TBI BMS recipients $(b$ and $c)$ and normal age-matched control B10.BR mouse lung $(d)$. Note intense staining of interstitial and alveolar cells, and perivascular areas of TBI BMS lung $(a)$ and the higher frequency of similar cells in the Cy/TBI BMS group $(b)$, which also exhibited the most intense bronchiolar epithelial staining $(c)$. Cells detected with alkaline-phosphatase conjugated antidigoxigenin antibody and BCIP/NBT as chromogen, no counterstain. $\times 100$, resolution power equivalent to $40 \times$ objective lens. Photos are representative of three similar experiments.

the lung, prematurely priming it for its encounter with the existent circulating monocytes and the imminent BM inoculum.

The pattern of staining for TGF 3 mRNA we observed in the interstitium and bronchiolar epithelium is consistent with the data of Pelton et al. (48) and Corrin et al. (49) in studies of patients with fibrosing lung disorders. Since circulating cytokines may also affect cellular activation in the lung, we determined the serum levels of TGF $\beta$ and other inflammatory cytokines on day 7 after BMT in our four treatment groups. We found that regardless of the presence of T cells, Cy administration was associated with the highest levels of circulating free TGF $\beta$ (rather than in its bound latent form) probably through monocyte/macrophage activation in response to the Cy-induced tissue damage. In fact, at this time point, the ratio of free/total TGF $\beta$ is increased sixfold in the $\mathrm{Cy} / \mathrm{TBI}$ treated groups (free/total ratio of 0.006 versus $0.001, P=0.003$ ) compared to the TBI groups whose ratios were not different from unmanipulated control mice. This is suggestive of a high level of secretion and enzymatic activity from TGF $\beta$ receptor-bearing (mannose-6-phosphate receptor) cells. Indeed, high levels of TGF $\beta$ are now considered predictive of systemic and lung fibrosis in mice (50) and humans $(51,52)$.

TGF $\beta$ preferentially induces the development of Th1 cells, i.e., those producing IL-2 and IFN $\gamma$ (53). The presence of high circulating levels of IFN $\gamma$ was dependent on the addition of allogeneic T cells to the BM inoculum. IFN $\gamma$ has been demonstrated to suppress the production of collagen by lung fibroblasts (54) and may be responsible for the lack of collagen increase in the face of the lung injury induced in our model. Since IFN $\gamma$ increases MHC class II expression, this may account for the significant levels of host MHC class II seen in the lungs of BMS mice. Of the other cytokines measured on day 7 post-BMT, only IL-6 increased in response to the irradiation (or the transplant of BM) but not to a statistically significant degree. TNF- $\alpha$ and IL-1 $\beta$ may have peaked and subsided earlier as has been shown previously by Xun et al. (55). The sustained levels of these cytokines in the other treatment groups (i.e., those receiving $\mathrm{Cy}$ or allogeneic $\mathrm{T}$ cells) highlights the in- 


\section{TGF $\beta$ Expression in Lung Post-BMT}

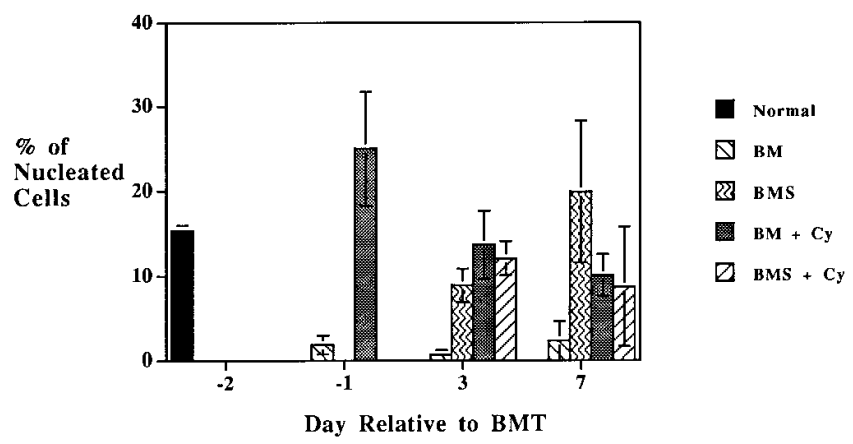

Figure 9. Expression of TGF $\beta$ mRNA as determined by in situ hybridization with antisense digoxigenin-labeled riboprobe. Data are expressed as the percentage of nucleated cells expressing TGF $\beta$ mRNA in the lung as determined by counting 4-9 fields per lung section under light microscope ( $20 \times$ objective lens). Each field contained an average of $\sim 500$ nucleated cells. Normal control level is indicated by solid bar. Mean values \pm SD are indicated for 2-3 mice per group per time point from two representative experiments.

tensity of the immune response especially for Cy/TBI mice receiving BMS where all cytokine levels measured were elevated and which displayed the highest mortality rate.

The infusion of allogeneic $\mathrm{T}$ cells clearly accelerated the early events associated with lung injury. Histologic analysis of the lungs from day 7 after BMT revealed evidence of extravasation and infiltration of mononuclear cells in mice which received allogeneic $\mathrm{T}$ cells (BMS groups) that was compounded by a mild to moderate degree of lung injury in mice receiving $\mathrm{Cy} / \mathrm{TBI}$. These findings were not homogeneous, but were seen in a focal pattern interspersed with normal appearing lung parenchyma as evidenced by electron microscopy. Except for edema, no dramatic changes were seen because of irradiation alone. This was expected since the irradiation dose used was below that needed to cause radiation pneumonitis in mice (56). The greater lung injury seen in mice receiving both TBI and Cy probably resulted from the greater dose intensity of cytoreductive therapy as reported by this laboratory (5). However this combined treatment is not sufficient without allogeneic $\mathrm{T}$ cells to result in persistent lung injury in our model since we could find no evidence of significant lung injury from our analysis of syngeneic recipients. It would be interesting to use lung shielding during irradiation to determine whether irradiationinduced injury is necessary to precipitate the damage induced by allogeneic $\mathrm{T}$ cells.

At the same time that donor $\mathrm{T}$ cells were infiltrating the lung, host MHC class II antigens were present in abundance. Increases in MHC class II expression have been shown for alveolar macrophages, and proliferating type II alveolar epithelial cells in human pulmonary fibrosis $(57,58)$. To our knowledge, upregulation of $\mathrm{B} 7$ molecules has not been demonstrated previously in the lung after BMT. The molecules B7-1 (CD80) and B7-2 (CD86) are expressed on antigen-presenting cells and provide costimulation to antigen-triggered $\mathrm{T}$ cells through the CD28/CTLA4 counterreceptors (59). In the absence of a costimulatory signal such as that mediated by B7, antigen-triggered $\mathrm{T}$ cells become nonresponsive or anergic
(60). Hence, in our murine IPS model, we have demonstrated the presence of all the necessary elements conducive to a localized antigen-driven immune response: tissue damage, host antigen presenting cells, donor $\mathrm{T}$ cells, and costimulatory molecules appropriate for preventing the induction of anergy. In our studies on the roles of $\mathrm{T}$ cell costimulatory pathways on GVHD after BMT across major histocompatibility barriers, we have demonstrated recently that blockade of the B7 stimulatory pathway can inhibit GVHD-induced lethality (61), but have not yet determined the effect on IPS generation. It is our hypothesis that intervention of such stimulatory pathways as caused by allorecognition will abrogate the development of IPS after BMT.

Although minor increases in $\mathrm{OH}$-proline accompanied decreases in pulmonary compliance and total lung capacity and was accompanied by increases in foci of macrophage infiltrates that became more severe over time, fibrosis was not prominent in this model. The recipient strain we used (B10.BR) may exhibit a delayed manifestation of radiation-induced pneumonitis as shown previously for other strains (56) and may not be as sensitive to Cy-induced fibrosis as BALB/c mice are, for example (19). A single injection of $\mathrm{Cy}(100 \mathrm{mg} / \mathrm{kg})$ produced an irreversible fibrosis in the lungs of the sensitive BALB/c mice (62). In this study, it was found that the presence of allogeneic $T$ cells was the most crucial element in increasing the wet and dry weights of the lungs (measures of blood-gas barrier injury). The same conclusion arose from the determination of specific lung compliance in air and total lung capacity. The presence of allogeneic donor $\mathrm{T}$ cells was the major contributor to the impairment of these lung function parameters, implicating immune-mediated mechanisms rather than chemoradiation as the critical injurious elements leading to IPS. Because recipients of allogeneic $\mathrm{T}$ cells and $\mathrm{Cy} / \mathrm{TBI}$ survived for a relatively brief period of time after BMT, the consequences of long-term lung injury induced under conditions most permissive for inducing pulmonary fibrosis and late-onset IPS could not be examined. The significance of lower numbers of allogeneic donor $\mathrm{T}$ cells in late onset pulmonary toxicity occurring after LPS injection has been demonstrated in a murine BMT system across minor histocompatibility differences $(6,14)$.

Although Cy/TBI preconditioning accelerated the cellular, cytokine, and costimulatory molecule expression in our study, the majority of these effects were only realized in the presence of allogeneic T cells. Therefore, for this murine system, IPS begins with initial tissue damage causing a host monocyte influx which can subside unless further exacerbated by a second wave comprised of host-recognizing T cells. Since some degree of allogenicity may be beneficial for preventing leukemic relapse and promoting BM engraftment in humans, measures to hinder the adhesion, extravasation and recruitment of the cells responsible for the initial inflammatory insult (i.e., monocytes) in the early post-BMT period may provide alternative strategies. Identification of these early events will aid in the targeting of components against which intervention strategies should be directed. Studies investigating these possibilities are currently in progress.

\section{Acknowledgments}

The expert technical assistance of Mark Petersen, Pat Jung, James $\mathrm{Xu}$, Robert McDonough, Bert Roers, Chris Lees, Kelly Coffey, John Bob Hermanson, and Ines de Llano is greatly appreciated. 
This study was supported by National Institutes of Health grant \#HL 55209, and the Morphology Core of the NIH Specialized Centers of Research in Acute Lung Injury grant P50 HL 50152.

\section{References}

1. Clark, J.G., J.A. Hansen, M.I. Hertz, R. Parkman, L. Jensen, and H.H. Peavy. 1993. Idiopathic pneumonia syndrome after bone marrow transplantation. Am. Rev. Respir. Dis. 147:1601-1606.

2. Weiner, R.S., M.M. Bortin, R.P. Gale, E. Gluckmann, H.E.M. Kay, J.H. Kolb, A.J. Hartz, and A.A. Rimm. 1986. Interstitial pneumonitis after bone marrow transplantation: assessment of risk factors. Ann. Intern. Med. 104:168-175.

3. Clift, R.A., C.D. Buckner, F.R. Appelbaum, S.I. Bearman, F.B. Petersen, L.B. Fisher, C. Anasetti, P. Beatty, W.I. Bensinger, K. Doney, et al. 1990. Allogeneic marrow transplantation in patients with acute leukemia in first remission: a randomized trial of two irradiation regimens. Blood. 76:1867-1871.

4. Petersen, F.B., H.J. Deeg, C.D. Buckner, F.R. Appelbaum, R. Storb, R.A. Clift, J.E. Sanders, W.I. Bensinger, R.P. Witherspoon, M. Sullivan, et al. 1992. Marrow transplantation following escalating doses of fractionated total body irradiation and cyclophosphamide: a phase I study. Int. J. Radiat. Oncol. Biol. Phys. 23:1027-1032.

5. Soderling, C.C.B., C.W. Song, B.R. Blazar, and D.A. Vallera. 1985. A correlation between conditioning and engraftment in recipients of MHC-mismatched $\mathrm{T}$ cell-depleted murine bone marrow transplants. J. Immunol. 135: 941-946.

6. Down, J.D., P. Mauch, M. Warhol, S. Neben, and J.L.M. Ferrara. 1992. The effect of donor T lymphocytes and total-body irradiation on hemopoietic engraftment and pulmonary toxicity following experimental allogeneic bone marrow transplantation. Transplantation (Baltimore). 54:802-808.

7. Gassmann, W., L. Uharek, H.-U. Wottge, N. Schmitz, H. Loffler, and W. Mueller-Ruchholtz. 1988. Comparison of cyclophosphamide, cytarabine, and etoposide as immunosuppressive agents before allogeneic bone marrow transplantation. Blood. 72:1574-1579.

8. Workman, D.L., and J. Clancy, Jr. 1994. Interstitial pneumonitis and lymphocytic bronchiolitis/bronchitis as a direct result of acute lethal graft-versushost disease duplicate the histopathology of lung allograft rejection. Transplantation (Baltimore). 58:207-213

9. Piguet, P.F., G.E. Grau, M.A. Collart, P. Vassalli, and Y. Kapanci. 1989. Pneumopathies of the graft-versus-host reaction. Alveolitis associated with an increased level of tumor necrosis factor mRNA and chronic interstitial pneumonitis. Lab. Invest. 61:37-45.

10. Holler, E., H.J. Kolb, J. Kempeni, S. Liesenfeld, H. Pechumer, W. Lehmacher, G. Ruckdeschel, B. Gleixner, C. Riedner, G. Ledderose, et al. 1990. Increased serum levels of tumor necrosis factor- $\alpha$ precede major complications of bone marrow transplantation. Blood. 75:1011-1016.

11. Xing, Z., M. Jordana, H. Kirpalani, K.E. Driscoll, T.J. Schall, and J. Gauldie. 1994. Cytokine expression by neutrophils and macrophages in vivo: endotoxin induces tumor necrosis factor- $\alpha$, macrophage inflammatory protein-2, interleukin-1 $\beta$, and interleukin- 6 but not RANTES or transforming growth factor- $\beta$ mRNA expression in acute lung inflammation. Am. J. Respir. Cell Mol. Biol. 10:148-153.

12. Ulich, T.R., E.S. Yi, S. Yin, C. Smith, and D. Remick. 1994. Intratracheal administration of endotoxin and cytokines. VII. The soluble interleukin-1 receptor and the soluble tumor necrosis factor receptor II (p80) inhibit acute inflammation. Clin. Immunol. Immunopathol. 72:137-140.

13. Ulich, T.R., S. Yin, D.G. Remick, D. Russell, S.P. Eisenberg, and T. Kohno. 1993. Intratracheal administration of endotoxin and cytokines. IV. The soluble tumor necrosis factor receptor type I inhibits acute inflammation. Am. J. Pathol. 142:1335-1338.

14. Cooke, K.R., L. Kobzik, T.R. Martin, J. Brewer, J. Delmonte, Jr., J.M. Crawford, and J.L.M. Ferrara. 1996. An experimental model of idiopathic pneumonia syndrome after bone marrow transplantation. I. The roles of minor $\mathrm{H}$ antigens and endotoxin. Blood. 88:3230-3239.

15. Haschek, W.M., and H. Witschi. 1979. Pulmonary fibrosis-a possible mechanism. Toxicol. Appl. Pharmacol. 51:475-487.

16. Haschek, W.M., A.J.P. Klein-Szanto, J.A. Last, K.M. Reiser, and H. Witschi. 1982. Long-term morphologic and biochemical features of experimentally induced lung fibrosis in the mouse. Lab. Invest. 46:438-449.

17. Fausto, N. 1991. Multifunctional roles for transforming growth factorbeta-1. Lab. Invest. 63:497-499.

18. Raghow, R. 1991. Role of transforming growth factor-beta in repair and fibrosis. Chest. 99:S61-S65.

19. Hoyt, D.G., and J.S. Lazo. 1989. Early increases in pulmonary mRNA encoding procollagens and transforming growth factor- $\beta$ in mice sensitive to cyclophosphamide-induced pulmonary fibrosis. J. Pharmacol. Exp. Ther. 249:38-43.

20. Bentzen, S.M., J.Z. Skoczylas, M. Overgaard, and J. Overgaard. 1996. Radiotherapy-related lung fibrosis enhanced by tamoxifen. J. Natl. Cancer Inst. 88:918-922.

21. Broekelmann, T.J., A.H. Limper, T.V. Colby, and J.A. McDonald. 1991. Transforming growth factor $\beta 1$ is present at sites of extracellular matrix gene expression in human pulmonary fibrosis. Proc. Natl. Acad. Sci. USA. 88:66426646.

22. Khalil, N., R.N. O'Connor, H.W. Unruh, P.W. Warren, K.C. Flanders, A. Kemp, O.H. Bereznay, and A.H. Greenberg. 1991. Increased production and immunohistochemical localization of transforming growth factor-beta in idiopathic pulmonary fibrosis. Am. J. Respir. Cell Mol. Biol. 5:155-162.

23. Fine, A., and R.H. Goldstein. 1987. The effect of transforming growth factor- $\beta$ on cell proliferation and collagen formation by lung fibroblasts. J. Biol. Chem. 262:3897-3902.

24. Kelley, J., E.J. Kovacs, K. Nicholson, J.P. Fabisiak. 1991. Transforming growth factor- $\beta$ production by lung macrophages and fibroblasts. Chest. 99 (Suppl.):85S-86S

25. Dusenbery, K.E., K.A. Daniels, J.S. McClure, P.B. McGlave, N.K.C. Ramsay, B.R. Blazar, J.P. Neglia, J.H. Kersey, and W.G. Woods. 1995. Randomized comparison of cyclophosphamide-total body irradiation vs. busulfancyclophosphamide conditioning in autologous bone marrow transplantation for acute myeloid leukemia. Int. J. Radiat. Oncol. Biol. Phys. 31:119-128.

26. Blazar, B.R., P.A. Taylor, D.C. Snover, J.A. Bluestone, and D.A Vallera. 1993. Nonmitogenic anti-CD3F $\left(\mathrm{ab}^{\prime}\right) 2$ fragments inhibit lethal murine graft-versus-host disease induced across the major histocompatibility barrier. $J$. Immunol. 150:265-277.

27. Blazar, B.R., P.A. Taylor, P.S. Linsley, and D.A. Vallera. 1994. In vivo blockade of CD28/CTLA4:B7/BB1 interaction with CTLA4-Ig reduces lethal murine graft-versus-host disease across the major histocompatibility complex (MHC) barrier in mice. Blood. 83:3815-3825.

28. Wangensteen, D., R. Piper, J.A. Johnson, A.A. Sinha, and D. Niewoehner. 1986. Solute conductance of blood-gas barrier in hamsters exposed to hyperoxia. J. Appl. Physiol. 60:1908-1916.

29. Berg, R.A. 1982. Determination of 3- and 4-hydroxyproline. Methods Enzymol. 82:372-398.

30. Wangensteen, D., R. Yankovich, J. Hoidal, and D. Niewoehner. 1983. Bleomycin-induced changes in pulmonary microvascular albumin permeability and extravascular albumin space. Am. Rev. Respir. Dis. 127:204-208.

31. Bachofen, H., J. Hildebrandt, and M. Bachofen. 1970. Pressure-volume curves of air- and liquid-filled excised lungs-surface tension in situ. J. Appl. Physiol. 29:422-431.

32. Blazar, B.R., P.A. Taylor, A. Panoskaltsis-Mortari, G.S. Gray, and D.A Vallera. 1995. Coblockade of the LFA1:ICAM and CD28/CTLA4:B7 pathways is a highly effective means of preventing acute lethal graft-versus-host disease induced by fully major histocompatibility complex-disparate donor grafts. Blood. 85:2607-2618.

33. Panoskaltsis-Mortari, A., and R.P. Bucy. 1995. In situ hybridization with digoxigenin-labeled RNA probes: facts and artifacts. Biotechniques. 18:300-308.

34. Mantel, N. 1966. Evaluation of survival data and two new rank order statistics arising in its consideration. Cancer Chemother. Rep. 50:163-170.

35. Ashcroft, T., J.M. Simpson, and V. Timbrell. 1988. Simple method of estimating severity of pulmonary fibrosis on a numerical scale. J. Clin. Pathol. (Lond.). 41:467-470.

36. Yousem, S.A., G.J. Berry, E.M. Brunt, D. Chamberlain, R.H. Hruban, R.K. Sibley, S. Stewart, and H.D. Tazelaar. 1990. A working formulation for the standardization of nomenclature in the diagnosis of heart and lung rejection: lung rejection study group. J. Heart Transplant. 9:593-601.

37. Pearson, A.E., and T.A. Phelps. 1981. Radiation effects on mouse incisor teeth following whole-body doses of up to 16 Gray. Int. J. Radiat. Biol. 39: 409-417.

38. Down, J.D., N.J. Tarbell, M. Warhol, and P. Mauch. 1988. Dose-limiting complications from upper half body irradiation in $\mathrm{C} 3 \mathrm{H}$ mice. Int. J. Radiat. Oncol. Biol. Phys. 14:483-489.

39. Goad, M.E.P., A.F. Tryka, and H.P. Witschi. 1987. Acute respiratory failure induced by bleomycin and hyperoxia: pulmonary edema, cell kinetics and morphology. Toxicol. Appl. Pharmacol. 90:10-22.

40. Bitterman, P.B., L.E. Saltzman, S. Adelberg, V.J. Ferrans, and R.G. Crystal. 1984. Alveolar macrophage replication. One mechanism for the expansion of the mononuclear phagocyte population in the chronically inflamed lung. J. Clin. Invest. 74:460-469.

41. Shami, S.G., M.J. Evans, and L.A. Martinez. 1986. Type II cell proliferation related to migration of inflammatory cells into the lung. Exp. Mol. Pathol. 44:344-352.

42. Curtis, J.L., P.K. Byrd, M.L. Warnock, and H.B. Kaltreider. 1991. Requirement of CD4-positive T cells for cellular recruitment to the lungs of mice in response to a particulate intratracheal antigen. J. Clin. Invest. 88:1244-1254.

43. Braciak, T.A., K. Bacon, Z. Xing, D.J. Torry, F.L. Graham, T.J. Schall, C.D. Richards, K. Croitoru, and J. Gauldie. 1996. Overexpression of RANTES using a recombinant adenovirus vector induces the tissue-directed recruitment of monocytes to the lung. J. Immunol. 157:5076-5084.

44. Wahl, S.M., D.A. Hunt, L.M. Wakefield, N. McCartney-Francis, L.M. Wahl, A.B. Roberts, and M.B. Sporn. 1987. Transforming growth factor type $\beta$ induces monocyte chemotaxis and growth factor production. Proc. Natl. Acad. Sci. USA. 84:5788-5792.

45. Postlethwaite, A.E., J. Keski-Oja, H.L. Moses, and A.H. Kang. 1987. Stimulation of the chemotactic migration of human fibroblasts by transforming growth factor $\beta$. J. Exp. Med. 165:251-256. 
46. Roberts, A.B., and M.B. Sporn. 1990. The transforming growth factor ßs. In Peptide Growth Factors and their Receptors. M.B. Sporn and A.B. Roberts, editors, Springer-Verlag, Heidelberg. 419-472.

47. Cooper, J.A.D., Jr., W.W. Merrill, and H.Y. Reynolds. 1986. Cyclophosphamide modulation of bronchoalveolar cellular populations and macrophage oxidative metabolism. Am. Rev. Respir. Dis. 134:108-114.

48. Pelton, R.W., M.D. Johnson, E.A. Perkett, L.I. Gold, and H.L. Moses. 1991. Expression of transforming growth factor- $\beta 1,-\beta 2,-\beta 3$ mRNA and protein in the murine lung. Am. J. Respir. Cell Mol. Biol. 5:522-530.

49. Corrin, B., D. Butcher, B.J. McAnulty, R.M. Dubois, C.M. Black, G.J. Laurent, and N.K. Harrison. 1994. Immunohistochemical localization of transforming growth factor- $\beta 1$ in the lungs of patients with systemic sclerosis, cryptogenic fibrosing alveolitis and other lung disorders. Histopathology (Oxf.). 24: $145-150$.

50. Zugmaier, G., S. Paik, G. Wilding, C. Knabbe, M. Bano, R. Lupu, B. Deschauer, S. Simpson, R.B. Dickson, and M. Lippman. 1991. Transforming growth factor- $\beta 1$ induces cachexia and systemic fibrosis without an antitumor effect in nude mice. Cancer Res. 51:3590-3594.

51. Anscher, M.S., W.P. Peters, H. Reisenbichler, W.P. Petros, and R.L. Jirtle. 1993. Transforming growth factor $\beta$ as a predictor of liver and lung fibrosis after autologous bone marrow transplantation for advanced cancer. N. Engl. J. Med. 328:1592-1598.

52. Murase, T., M.S. Anscher, W.P. Petros, W.P. Peters, and R.L. Jirtle. 1995. Changes in plasma transforming growth factor $\beta$ in response to high-dose chemotherapy for stage II breast cancer: possible implications for the prevention of hepatic veno-occlusive disease and pulmonary drug toxicity. Bone Marrow Transplant. 15:173-178.

53. Nagelkerken, L., K.J. Collob, M. Tielemans, and R.L. Coffman. 1993. Role of transforming growth factor- $\beta$ in the preferential induction of $\mathrm{T}$ helper cells of type 1 staphylococcal enterotoxin B. Eur. J. Immunol. 23:2306-2310.

54. Elias, J.A., B. Freundlich, J.A. Kern, and J. Rosenbloom. 1990. Cytokine networks in the regulation of inflammation and fibrosis in the lung. Chest.
97:1439-1445

55. Xun, C.Q., J.S. Thompson, C.D. Jennings, S.A. Brown, and M.B. Widmer. 1994. Effect of total body irradiation, busulfan-cyclophosphamide, or cyclophosphamide conditioning on inflammatory cytokine release and development of acute and chronic graft-versus-host disease in $\mathrm{H}-2$ incompatible transplanted scid mice. Blood. 83:2360-2367.

56. Down, J.D., D. Nicholas, and G.G. Steel. 1986. Lung damage after hemithoracic irradiation: dependence on mouse strain. Radiother. Oncol. 6:43-50.

57. Kallenberg, C.G.M., B.M. Schilizzi, F. Beaumont, L.D.E. Leij, S Poppema, and T.H. The. 1987. Expression of class II major histocompatibility complex antigens on alveolar epithelium in interstitial lung disease: relevance to pathogenesis of idiopathic pulmonary fibrosis. J. Clin. Pathol. (Lond.). 40 $725-733$.

58. Komatsu, T., M. Yamamoto, K. Shimokata, and H. Nagura. 1989. Phenotypic characterization of alveolar capillary endothelial cells, alveolar epithelial cells and alveolar macrophages in patients with pulmonary fibrosis, with special reference to MHC class II antigens. Virchows Archiv. Abt. Pathol. Anat. 415:79-90.

59. June, C.H., J.A. Bluestone, L.M. Nadler, and C.B. Thompson. 1994. The B7 and CD28 receptor families. Immunol. Today. 15:321-331.

60. Schwartz, R.H. 1992 Costimulation of T lymphocytes: the role of CD28, CTLA-4, and B7/BB1 in interleukin-2 production and immunotherapy. Cell. 71 : 1065-1068.

61. Blazar, B.R., A.H. Sharpe, P.A. Taylor, A. Panoskaltsis-Mortari, G.S Gray, R. Korngold, and D.A. Vallera. 1996. The infusion of anti-B7.1 (CD80) and anti-B7.2 (CD86) monoclonal antibodies inhibits murine graft-versus-host disease lethality in part via direct effects on $\mathrm{CD}^{+}$and $\mathrm{CD} 8^{+} \mathrm{T}$ cells. J. Immunol. 157:3250-3259.

62. Morse, C.C., C. Sigler, S. Lock, P.J. Hakkinen, W.M. Haschek, and H.P. Witschi. 1985. Pulmonary toxicity of cyclophosphamide: a 1-year study. Exp. Mol. Pathol. 42:251-260. 